\title{
PENERAPAN SISTEM AKUNTANSI UNTUK MENGOPTIMALISASI PEMASARAN UMKM SAGALA LADA DI KELURAHAN CIBABAT
}

\author{
Annisa Nurfitriana \\ nurfitrianannisa09@gmail.com \\ Nurul Fatimah \\ nurulfatimah.upi@gmail.com \\ Hana Fadhilah \\ hana_fadhilah22@yahoo.com
}

SEKOLAH TINGGI ILMU EKONOMI EKUITAS

\begin{abstract}
ABSTRAK
Kegiatan pengabdian ini bermaksud membantu penyelesaian beberapa permasalahan yang dihadapi oleh sebuah Usaha Kecil Menengah (UKM) rumahan bernama "Dapur Sagala Lada". Permasalahan yang dihadapi diantaranya berkaitan dengan sistem produksi, pemasaran dan keuangan. Metode yang digunakan dalam menyelesaikan permasalahanpermasalahan tersebut diawali dari tahap penelusuran masalah dan kebutuhan, perancangan solusi, dan implementasi. Penelusuran masalah dilakukan melalui metode survei dan wawancara di lokasi usaha. Berdasarkan permasalahan yang ada, tim memutuskan untuk memberikan kontribusi berupa peralatan dan rancangan sistem akuntansi. Dengan bantuan tersebut, UKM Sagala lada dapat berproduksi secara masal dan meningkatkan potensi penghasilannya. Adapun sistem akuntansi yang dirancang oleh tim memungkinkan UKM Sagala Lada menyajikan informasi keuangan yang dibutuhkan sebagai prasyarat pengajuan nomor Pangan Industri Rumah Tangga (PIRT)..
\end{abstract}

Kata kunci: Sistem Akuntansi, Usaha Kecil Menengah, Cimahi.

\section{PENDAHULUAN}

\subsection{Analisis Situasi}

Kegiatan pengabdian ini dilakukan pada sebuah industri rumahan bernama "Dapur Sagala Lada".Nama "lada" yang berarti pedas dalam bahasa Sunda digunakan karena produk makanan yang diproduksinya sebagian besar bercita rasa pedas.Dapur Sagala Lada didirikanpada tahun 2015 di Kelurahan Cibabat Kota Cimahiyang fokus pada produksi makanan ringan makaroni dalam kemasan.
Berdasarkan observasi dan wawancara ke lokasi usaha, berikut uraian analisis proses bisnis Dapur Sagala Lada.

\subsubsection{Sistem Produksi}

Dapur Sagala Lada memproduksi dua jenis makanan ringan, yaitu makaroni dan kerupuk seblak.Untuk jenis makaroni, terdapat dua varian produk berdasarkan segmen pasarnya, yakni makaroni untuk dewasa dan makaroni untuk anak.Makaroni dewasa memiliki 4 (empat) varian rasa yang hampir semua bercita rasa asin dan pedas, 
sedangkan untuk anak diberikan rasa yang cenderung manissesuai selera anak-anak (Lihat Tabel 1.1). Sementara itu, kerupuk seblak hanya memiliki satu varian yakni rasa asin pedas.

Tabel 1.1

Variasi Produk Makaroni Sagala Lada

\begin{tabular}{|c|c|c|}
\hline $\begin{array}{c}\text { Jenis } \\
\text { Produk }\end{array}$ & Segmen & Varian Rasa \\
\hline \multirow{4}{*}{ Makaroni } & \multirow{2}{*}{ Dewasa } & Pedas \\
\cline { 3 - 3 } & & Rendang \\
\cline { 3 - 3 } & \multirow{2}{*}{ Jagung Bakar } \\
\cline { 3 - 3 } & \multirow{2}{*}{ Anak } & Balado \\
\cline { 3 - 3 } & & Jagung Manis \\
\cline { 3 - 3 } & & Keju \\
\hline Kerupuk & - & Seblak \\
\hline
\end{tabular}

Dapur Sagala Lada melakukan produksi dengan metode Just in Time(JIT), yakni hanya melakukan produksi ketika ada pesanan. Metode ini dipilih karena belum tersedianya fasilitas tempat dan alat yang dapat digunakan untuk menyimpan bahan baku maupun hasil produksiagar tahan lama. Modal yang tersedia pun belum cukup untuk melakukan produksi secara masal dan kontinyu, sehingga setiap agenda produksi hanya dilakukan jika ada potensi penghasilan yang lebih pasti, yakni pesanan. Ketika ada pesanan datang, pemilik langsung melakukan pembelian bahan baku dan melakukan produksi sesuai jumlah yang dipesan. Semua proses produksi dilakukan sendiri oleh pemilik usaha karena sejauh ini skala usaha dan modal masih dirasakan kecil serta semua prosesnya masih dapat dikerjakan sendiri.Hasil produksi kemudian segera dikirimkan kepada pelanggan/agen/reseller yang memesan sesuai harga yang ditentukan.

Saat ini, produk-produk Dapur Sagala Lada telah mendapatkan label halal dari Majelis Ulama Indonesia (MUI) dan telah diuji masa kadaluwarsanya di beberapa laboratoriumperguruan tinggi di Bandung. Secara rata-rata, makaroni Sagala Lada baik untuk dikonsumsi dalam kurun waktu kurang dari 3 bulan.

Kendati demikian produk ini belum mendapatkan nomor Pangan Industri Rumah Tangga (PIRT) dari Dinas Kesehatan setempat.Perizinan PIRT diperlukan sebagai jaminan usaha makanan/minuman rumahan yang dijual dan beredar di masyarakat memenuhi standar keamanan makanan atau izin edar produk pangan (Badan Pengawas Obat dan Makanan Republik Indonesia, 2012).Beberapa toko di wilayah Cimahi kadang mempertanyakan sertifikat PIRT ini sebelum menampung produk Sagala Lada. Namun, hingga saat ini - setelah satu tahun lamanya - nomor PIRT Sagala Lada masih dalam proses pengurusan karena terkendala persyaratancatatan keuangan. Selain PIRT, Sagala Lada juga tengah mengajukan HKI merk dagang "Sagala Lada" untuk memperkuat posisinya di pasaran.

\subsubsection{Sistem Pemasaran}

Produk Sagala Lada dipasarkan dengan dua cara, yakni secara konvensional (offline) dan berbasis daring (online). Pada metode offline, terdapat 3 (tiga) tahapan pemasaran sesuai dengan kuantitas yang dijual, mulai dari agen, reseller dan eceran. Semakin banyak barang yang dijual maka harga satuan akan semakin murah dan sebaliknya.

Hingga saat ini, jumlah agen Dapur Sagala Lada semakin berkembang dan tersebar di beberapa daerah di Indonesia seperti Sabang, Pekanbaru, Palembang, Bangka Belitung, Lampung, Jabodetabek, Semarang, dan Klaten. Pada umumnya agen-agen tersebut merupakan Ibu Rumah Tangga (IRT) yang memiliki hubungan pertemanna dengan pemilik usaha.Agenagen tersebut membeli produkSagala Lada dalam jumlah besar ( $\geq 100$ kemasan), lalu menjualnya kembali kepada para reseller yang juga sebagian besar merupakan IRT yang tidak bekerja.

Menurut penuturan pemilik, para IRT tersebut sengaja dipilih sebagai reseller dengan tujuan memberdayakan mereka agar 
memiliki aktivitas yang produktif dan bermanfaat. Disamping itu, IRT masa kini memiliki potensi besar sebagai pemasar yang baik karena akrab dengan media sosial dan cenderung aktif dalam komunitaskomunitas tertentu.

Sementara itu, penjualan secara eceran dilakukan melalui metode konsinyasi di beberapa toko oleh-oleh di wilayah Kota Cimahi.Penjualan melalui cara ini dirasakan cukup sulit karena terdapat banyak kompetitor yang berani menjual dengan harga lebih murah serta mahalnya biaya yang dikeluarkan karena sistem konsinyasi. Disamping itu, pemilik sulit mendapatkan personil marketing yang handal untuk memasarkan produknya ke berbagai toko.Meskipun cakupannya masih terbatas, namun penghasilan dari jalur ini cukup memuaskan.

Untuk menjangkau wilayah yang lebih luas, pemilik pun memasarkan produknya melalui beberapa situs jual beli online, salah satunya adalah Bukalapak.com. Pada metode ini, produk dijual secara eceran namun dengan tingkat harga yang lebih tinggi.Dibandingkan dengan metode offline, penjualan dari jalur online ini memberikan penghasilan yang jauh lebih besar karena biaya yang dikeluarkan pun relatifrendah.

\subsubsection{Sistem Keuangan}

Dapur Sagala Lada memulai usahanya dengan modal sendiri yang berasal dari simpanan pribadi pemilik. Hingga saat ini pun modal usaha masih merupakan modal pribadi tanpa adanya tambahandana kredit ataupun investasi dari pihak lain. Pemilik usaha memiliki preferensi untuk tetap bertumpu pada modal sendiri dan tidak berkeinginan untuk menerima kredit usaha perbankan baik yang berbasis konvensional maupun syariah.

Hingga saat ini pembukuan UKM Dapur Sagala Lada masih belum memadai.Pengelolaan keuangan pribadi dan perusahaan masih tercampur, atau belum diterapkannya konsep kesatuan usaha (entity concept).Selain itu, tidak adanya pencatatan secara rutin dan konsisten untuk setiap transaksi pembelian ataupun penjualan yang terjadi. Sama halnya dengan proses produksi, proses pembukuan juga dilakukan sendiri oleh pemilik yang juga seorang IRT. Karena kesibukannya sebagai IRT, pemilik terkadang mencatat transaksi yang terjadi secara manual pada sebuah catatan, namun tidak dilakukan secara rutin.Konsekuensinya, pemilik tidak mengetahui secara akurat nominal biaya produksi dan keuntungan (profit) yang diperoleh usahanya di akhir periode. Kendati pemilik menyebutkan bahwa profit yang ia dapatkan cukup banyak - hingga $40 \%$ - namun angka tersebut masih merupakan perkiraan kasar dan masih harus dikritisi.

\subsection{Permasalahan Mitra}

Berdasarkan uraian diatas, terdapat beberapa permasalahan penting yang perlu ditindaklanjuti, antara lain sebagai berikut:

\subsubsection{Permasalahan Produksi}

Salah satu kendala dalam proses produksi adalah belum tersedianya tempat atau fasilitas yang memungkinkan pemilik menyimpan hasil produksinya agar tahan lama. Salah satu faktor yang menurunkan kualitas makaroni adalah jika ia terkena paparan sinar matahari terlalu lama, terkena udara atau suhu yang terlalu tinggi atau rendah. Hal inilah yang menyebabkan pemilik tidak dapat memproduksi makaroni secara masal dan tidak dapat langsung memenuhi pesanan yang datang.

\subsubsection{Permasalahan Pemasaran}

Telah dikemukakan bahwa pemilik UKM Sagala lada mengerjakan semua proses bisnisnya sendiri, termasuk dalam memasarkan produknya.Pemilik melakukan promosi ke berbagai segmen hanya ketika ada waktu luang (ketika tidak ada pesanan). Hal ini menyebabkan proses branding produk berjalan sangat lambat dan sulit berkembang. Berdasarkan pengalaman pemilik, sebelumnya sempat ada beberapa orang yang direkrut sebagai tim marketing produk ini, namun rata-rata dari mereka cepat menyerah dalam menghadapi berbagai 
penolakan. Bagi pemilik, mencari orang yang berjiwa entrepreneur memang sulit dan hingga saat ini masih belum ditemukan.

Pada pemasaran jalur agen seringkali pula ditemukan kendala.Agen-agen yang sebagian besar merupakan IRT seringkali tidak fokus dalam memasarkan produknya.Kemungkinanhal tersebut disebabkan karena kesibukan sebagai IRT dan pola pikir yang menganggap bisnis ini hanya usaha sampingan untuk menambah pendapatan.Akibatnya, pesanan melalui jalur ini seringkali timbul-tenggelam dan kurang optimal. Para agen atau reseller juga terkadang belum memahami cara menjaga citra di media sosial, sehingga menurunkan minat konsumen untuk membeli produknya. Khusus di daerah sekitar industri ini berada, daya beli masyarakat dirasakan masih rendah.Masyarakat lebih menyenangi produk kompetitor yang dijual dengan harga lebih murah dan tidak kritis terhadap kualitas komposisi bahannya.Padahal berdasarkan sebuah penyelidikaan, produkproduk yang sangat murah tersebut diproduksi dengan bahan yang kurang sehat, seperti minyak curah dan pewarna kimiawi yang tidak terstandar.

\subsubsection{Permasalahan Akuntansi/ Keuangan}

Masalah akuntansi menjadi persoalan yang cukup krusial bagi UKM ini.Hal tersebut dikarenakan dampak dari kurang memadainya catatan keuangan menghambat upaya pemilik untuk mendapatkan nomor PIRT.Padahal nomor PIRT ini salah satu kunci dalam memasarkan produk ke toko/gerai dan menumbuhkan kepercayaan konsumen.

Kurang memadainya sistem akuntansi pada UKM ini ditengarai beberapa faktor.Pertama, pemilik tidak memiliki keinginan mengajukan kredit perbankan.Sebagian besar UKM yang membenahi akuntansinya bertujuan agar memperoleh kredit dari bank.Sedangkan UKM ini tidak, oleh karenanya mereka tidak termotivasi dan menganggap pencatatan keuangan tidak terlalu penting.Padahal sebenarnya, fungsi pencatatan keuangan bukan hanya untuk tujuan aplikasi kredit, namun lebih dari itu,yakni untuk menentukan harga pokok penjualan (HPP) dan laba usaha (profit margin) yang didapatkan.

Kedua, karena pencatatan keuangan dilakukan oleh pemilik sendiri yang merupakan IRT, terkadang kesibukannya menjadi kesulitan untuk mencatat segala transaksi secara konsisten.Pembukuan yang kurang memadai pun menjadi salah satu penghambat UKM Sagala lada meningkatkan skala usahanya melalui pembukaan kesempatan investasi.Pemilik menyadari bahwa jika ingin mendapatkan investor untuk usahanya, mereka harus dapat menyajikan laporan keuangan secara transparan.

\subsection{Solusi}

Solusi dari permasalahan yang dihadapi oleh UMKM Sagala Lada, diantaranya :

a. Menyediakan tempat berupa rak dan etalase untuk menyimpan produk yang sudah jadi dan stok agar tidak terkontaminasi dengan suhu dari proses produksi.

b. Adanya pendampingan dalam penerapan jiwa wirausaha kepada karyawan yang akan membantu usaha pelaku UMKM.

b. Adanya nomor PIRT untuk membantu pelaku usaha untuk mempermudah pelaku memasuki pasar dengan kompetitor lain.

c. Adanya penambahan karyawan untuk membantu usaha pelaku UMKM.

d. Adanya sistem akuntansi yang dapat membantu pelaku dalam melaporkan laporan keuangan usaha sehingga kendala keuangan dapat diatasi

\section{METODE PELAKSANAAN}

Berdasarkan permasalahan yang terjadi di Makaroni Sagala Lada, berikut adalah metode yang dilaksanakan dalam pengabdian kepada masyarakat, yaitu: 


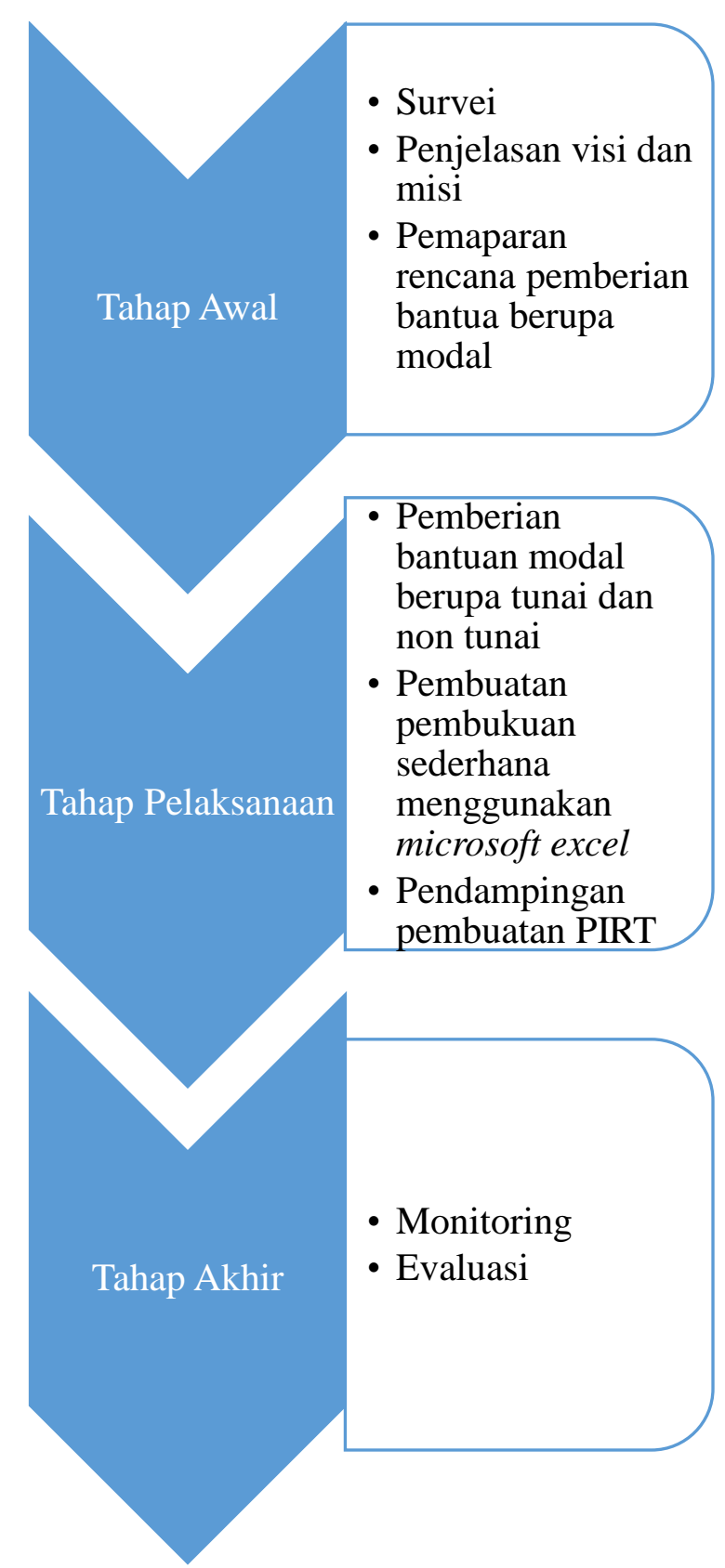

Gambar 2.1

Metode Pelaksanaan

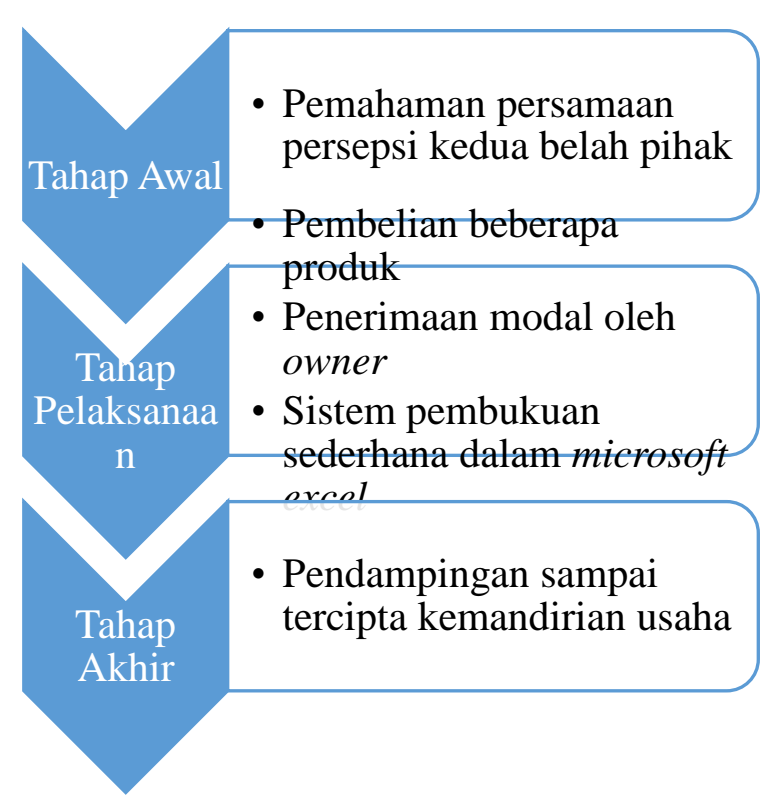

Gambar 2.2

Gambaran Hasil

\section{HASIL DAN LUARAN}

\subsection{Pelaksanaan Pengabdian}

Kegiatan pengabdian yang tim kami lakukan adalah dengan melakukan survei awal yang bertujuan untuk mengetahui secara mendalam mengenai Dapur Sagala Lada. Kegiatan survei awal ini dilakukan pada hari Jumat tanggal 26 Januari 2018. Berikut ini adalah dokumentasi dari kegiatan tersebut.

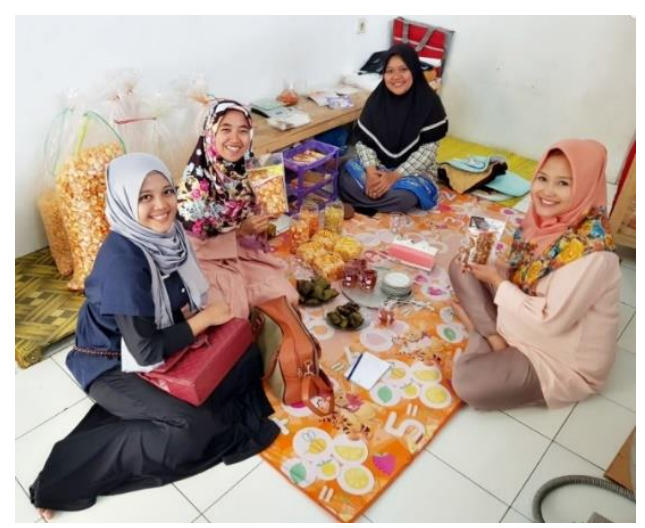

. Gambar 3.1

Berfoto Bersama Pemilik Dapur Sagala Lada pada Saat Survei Awal 
Setelah melakukan survei awal, maka selanjutnya tim kami membuat beberapa perbaikan terhadap kegiatan bisnis Dapur Sagala Lada. Perbaikan tersebut diantaranya:

\subsubsection{Pengadaan Alat Berupa Etalase}

Salah satu yang dibutuhkan Dapur Sagala Lada adalah adanya etalase untuk menyimpan barang jualan yang sudah dikemas. Oleh karena itu, disini tim kami memberikan sebuah etalase kaca berukuran 1,5 meter. Berikut ini adalah dokumentasi dari etalase yang tim kami berikan

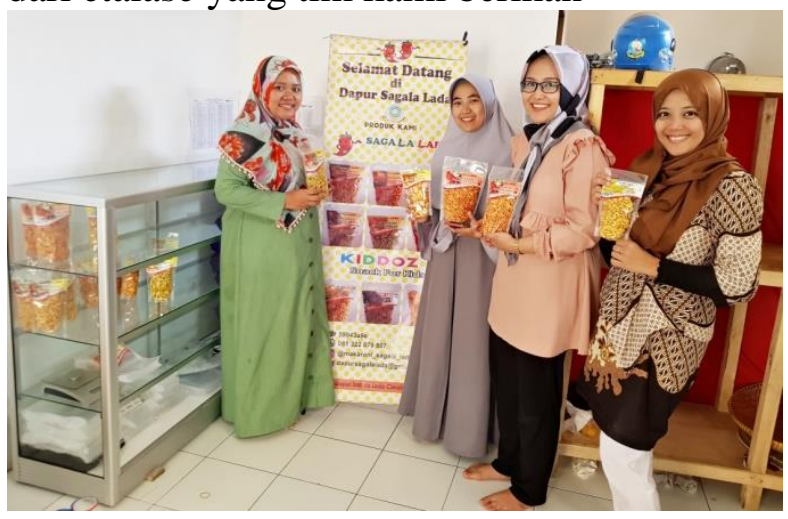

Gambar 3.2

Berfoto Bersama Pemilik

Dapur Sagala Lada pada Saat Survei Akhir

\subsubsection{Sistem Informasi Akuntansi}

Permasalahan selanjutnya yang dihadapi oleh Dapur Sagala Lada adalah belum diperolehnya nomor PIRT bagi produkproduknya. Upaya mendapatkan nomor PIRT ini terkendala oleh belum adanya sistem pembukuan yang memadai di Dapur Sagala Lada. Oleh karena itu, tim kami berupaya memberikan kontribusi pemikiran dengan membuat sistem pembukuan otomatis sederhana menggunakan softwareMicrosoft Excel.
Tabel 3.1

Nomor Akun

\begin{tabular}{|c|c|c|}
\hline Ho. Po: & Hama-Kama pos & $\checkmark$ \\
\hline 1 & Aset & \\
\hline 1.1 & Kas & \\
\hline 1.2 & Piutang & \\
\hline 1.3 & Pyrlengkapen & \\
\hline 1.4 & Prraedisan & \\
\hline 1.5 & Peralatan & \\
\hline 2 & Kewajiban & \\
\hline 2.1 & Ultang Ulashs & \\
\hline 2.2 & Ultang Komisi & \\
\hline 3.1 & Modsl & \\
\hline 3.2 & Prive & \\
\hline 4 & $\rho_{\text {endapatan }}$ & \\
\hline 4.1 & Penjualan offline & \\
\hline 4.2 & penjualan konainyasi & \\
\hline 4.3 & Penjuslen online & \\
\hline 5 & Beban & \\
\hline 5.1 & Bebsen trensportesi & \\
\hline 5.2 & Beben sqwe & \\
\hline 5.3 & Bebon Ulpah & \\
\hline 5.4 & Baben komisi online & \\
\hline 5.5 & Bebsen komuniksai & \\
\hline 5.6 & Beben liatrik & \\
\hline
\end{tabular}

Tabel 3.1 memuat semua akun yang ada di Dapur Sagala Lada. Nomor akun ini digunakan untuk memudahkan pengklasifikasian transaksi yang terjadi sesuai klasifikasinya masing-masing.

Tabel 3.2

Klasifikasi Akun

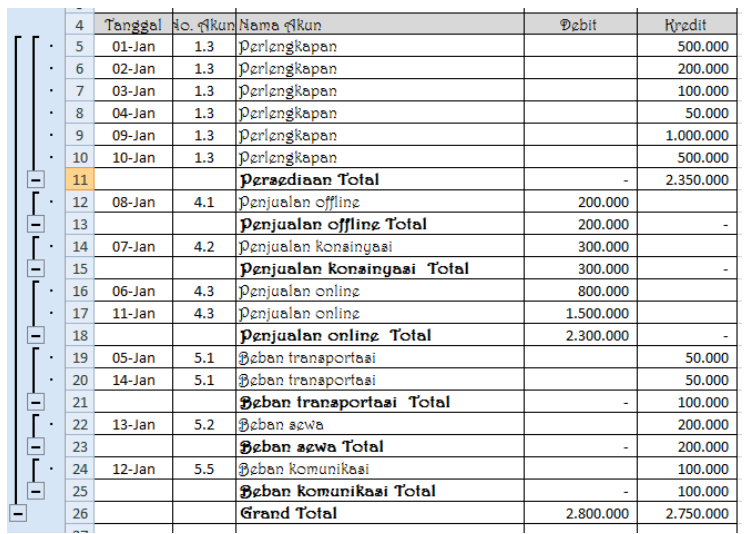

Tabel 3.2 menjelaskan tentang gambaran umum transaksi yang terjadi selama beberapa hari. Dari tabel tersebut nantinya akan dijumlahkan sesuai dengan klasifikasinya masing-masing sehingga memudahkan Dapur Sagala Lada untuk mengetahui jumlah keseluruhan penerimaan atau pengeluaran dari setiap akunnya. 
Tabel 3.3

Laporan Laba Rugi dan Laporan Perubahan

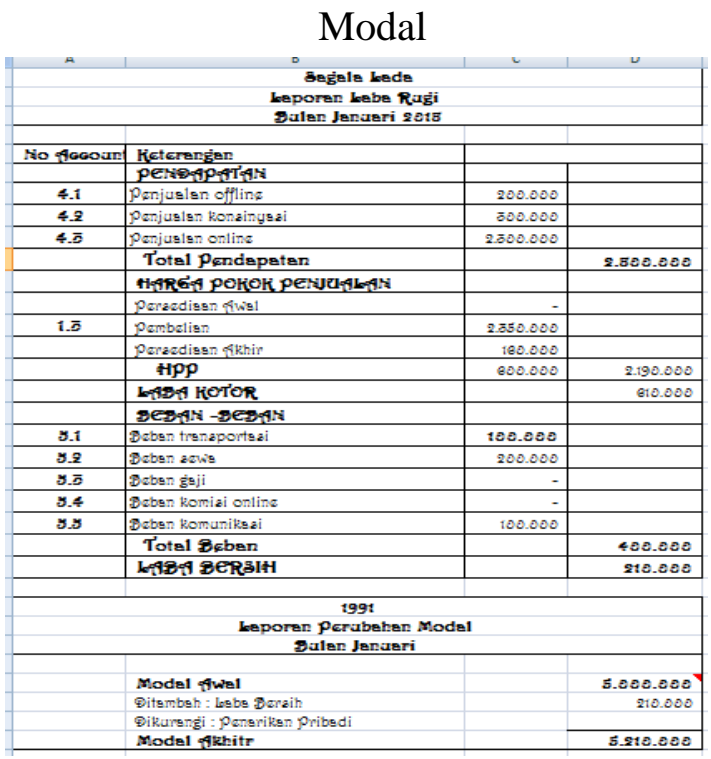

Setelah semua transaksi di jumlahkan sesuai dengan akunnya masing-masing, maka tahapan selanjutnya adalah pembuatan laporan keuangan. Laporan keuangan sederhana yang diterapkan pada Dapur Sagala Lada adalah laporan sederhana berupa Laporan Laba Rugi dan Laporan Perubahan Modal. Dalam Tabel 3.3 digambarkan bahwa jumlah pendapatan dan beban berasal dari jumlah akun yang sudah di klasifikasikan pada Tabel 3.2 sehingga Dapur Sagala Lada hanya memindahkan angka saja, yang nantinya dapat diperoleh laba bersih di akhir periode. Laporan Perubahan Modal menggambarkan tentang kondisi modal Dapur Sagala Lada pada akhir periode. Tabel 3.3 menggambarkan bahwa modalDapur Sagala Lada mengalami peningkatan karena ada tambahan dari perolehan laba bersih.

Program yang kami rancang ini hanya berupa sebuah file excel yang terdiri dari 5 sheets yang terintegrasi satu sama lainnya, yakni diantaranya:
1. Sheet1 : Data Pokok

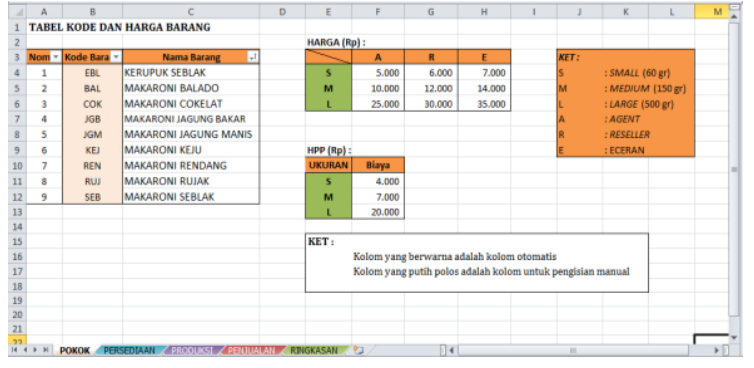

Gambar 3.3 Aplikasi Akuntansi Sheet 1: Data Pokok

Pada sheet pertama ini, dicantumkan data pokok dari produk-produk yang dijual seperti kode barang, harga jual dan harga pokok penjualan masing-masing produk. Dapur Sagala Lada saat ini memiliki 9 (sembilan) varian produk, delapan diantaranya berjenis makaroni, dan satu lainnya adalah kerupuk. Untuk memudahkan identifikasi dari kesembilan produk tersebut, maka pengkodean perlu dilakukan.

Kode barang dibuat dengan tujuan mengotomatisasi penginputan data transaksi setiap barang dengan cepat dan praktis ke setiap sheet lainnya dibandingkan harus mengetikkan nama barang secara lengkap. Pengkodean barang disini menggunakan sistem mnemonik, yakni menggabungkan tiga huruf yang mewakili nama barangnya. Adapun kolom kode barang (kolom B) diotomatisasi menggunakan rumus berikut.

$$
=I F(I S B L A N K(C 4) ; " \text { "' } M I D(C 4 ; 10 ; 3))
$$

Pada tabel harga jual barang dilakukan pembedaan harga jual produk berdasarkan ukuran kemasan (Small (S); Medium (M); Large (L)) dan jalur pemasarannya (Agent (A); Reseller (R); Eceran (E)). Semakin banyak kuantitas barang yang dijual maka harga jual per unit semakin murah. Berikut daftar harga jual yang ditetapkan oleh Dapur Sagala Lada. 
Tabel 3.4 Daftar Harga Jual Produk (Rp)

\begin{tabular}{|c|c|c|c|}
\hline & $\mathbf{A}$ & $\mathbf{R}$ & $\mathbf{E}$ \\
\hline $\mathbf{S}$ & 5.000 & 6.000 & 7.000 \\
$\mathbf{M}$ & 10.000 & 12.000 & 14.000 \\
$\mathbf{L}$ & 25.000 & 30.000 & 35.000 \\
\hline
\end{tabular}

Selain harga jual, perlu juga dimasukkan data harga pokok penjualan (HPP) agar pada akhir periode dapat diketahui berapa laba atau rugi yang diterima oleh Dapur Sagala Lada. HPP produk pada usaha ini dibedakan berdasarkan ukuran kemasan. Semua varian rasa diasumsikan memiliki modal yang sama, meskipun pada faktanya berbeda. Produsen berpendapat jika diberlakukan pembedan harga berdasarkan varian rasa, respon pelanggan cenderung negatif. Oleh karena itu, cara menyiasatinya adalah dengan melakukan subsidi silang antara varian rasa yang menelan biaya produksi rendah terhadap varian rasa yang memiliki biaya tinggi.

Pemikiran tersebut masih diterima karena skala usaha yang tengah dijalani ini masih kecil dan produk yang dijual bersifat homogen. Namun, sistem seperti ini tidak akan efisien jika diterapkan di perusahaan yang berskala menengah keatas karena akan menyebabkan penetapan harga yang tidak kompetitif, bisa underpriced atau overpriced. Perusahaan skala besar harus menerapkan sistem Activity Based Costing (ABC) dalam penetapan HPP-nya. Berikut ini daftar HPP produk masing-masing ukuran kemasan:

Tabel 3.5 HPP Produk

\begin{tabular}{|c|cc|}
\hline Ukuran & Isi (gram) & Biaya (Rp) \\
\hline S & 60 & 4.000 \\
M & 150 & 7.000 \\
L & 500 & 20.000 \\
\hline
\end{tabular}

2. Sheet 2 : Produksi

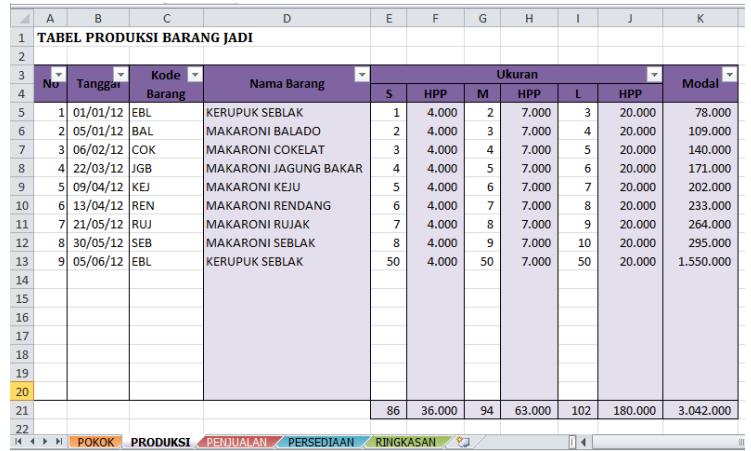

Gambar 3.4 Aplikasi Akuntansi Sheet2:

Hasil Produksi Barang

Keterangan : Angka yang tertera pada gambar merupakan simulasi

Lembar kedua ini menampilkan rincian jumlah dan jenis produk yang dihasilkan setiap kali produksi. Di dalam aplikasi sederhana ini tidak dimasukkan data tentang proses produksi dari bahan mentah menjadi barang jadi karena terlalu rumit untuk sebuah UMKM. Oleh karenanya, barang atau persediaan yang ada dianggap sudah dalam bentuk barang jadi layaknya pada perusahaan dagang.

Langkah pengisian lembar ini sangat sederhana. Setiap kali selesai produksi, pemilik tinggal menginputkan tanggal (kolom B), kode barang (kolom C) dan kuantitas setiap varian produk berdasarkan ukuran kemasannya (kolom $\mathrm{F}, \mathrm{H}$ dan $\mathrm{J}$ ) secara manual. Adapun kolom nama barang (kolom D) akan terisi otomatis dengan rumus berikut:

$=I F(I S B L A N K(C 5) ; "$ "; VLOOKUP(C5; POKOK! $\$ B \$ 4: \$ C \$ 16 ; 2 ; F A L S E))$

Kolom HPP setiap ukuran akan terisi dengan cara membuat hubungan (link) dengan sheet 1 pada tabel HPP.

\section{Sheet 3 : Penjualan}

Sheet 3 memiliki fungsi yang sama dengan jurnal penjualan, yakni bertujuan mencatat seluruh transaksi penjualan yang terjadi, baik secara tunai maupun kredit. Berdasarkan cara pemasarannya, kini Dapur 
Sagala Lada lebih mengutamakan penjualan secara tunai yang diperoleh melalui pasar online, baik untuk partai kecil maupun besar. Pemasaran secara offflineyang pembayarannya bersifat tidak tunai masih dilakukan, namun secara terbatas. Pada aplikasi ini, pemilik Dapur Sagala Lada tidak merasa perlu untuk membedakan jurnal penjualan berdasarkan metode pemasarannya karena dirasa terlalu rumit. Oleh karena itu, semua penjualan diasumsikan bersifat tunai

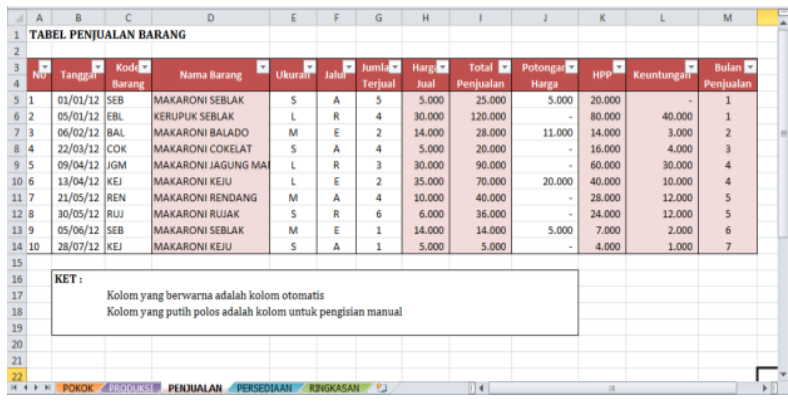

Gambar 3.5 Aplikasi Akuntansi Sheet 3: Penjualan

Pada gambar diatas, pemilik Dapur Sagala Lada perlu menginput delapan kolom secara manual, yakni kolom-kolom berwarna putih. Sedangkan kolom-kolom yang berwarna merah akan otomatis terisi dengan menggunakan rumus sebagai berikut

a. Kolom D : Nama BarangPengisian pada kolom ini sama seperti pada sheet sebelumnya.

b. Kolom H : Harga Jual

$=I F(F 5=" A " ; V L O O K U P(E 5 ; P O K O K ! \$ E \$ 4: \$ H \$ 6 ;$
$2 ; F A L S E) ; I F(F 5=" R " ; V L O O K U P$
$(E 5 ; P O K O K ! \$ E \$ 4: \$ H \$ 6 ; 3 ; F A L S E) ;$
$V L O O K U P(E 5 ; P O K O K ! \$ E \$ 4: \$ H \$ 6 ; 4 ; F A L S E)))$

c. Kolom I : Total Penjualan

$$
=G 5 * H 5
$$

d. Kolom K : HPP

$=$ IF $(I S B L A N K(E 6) ; "$; $(G 6 *($ VLOOKUP
$(P E N J U A L A N !$ E6;
POKOK! $\$ E \$ 11: \$ F \$ 13 ; 2 ;$ FALSE $))))$

e. Kolom L : Keuntungan / Laba :

$=$ SUMIFS(PENJUALAN! $\$ G \$ 5: \$ G \$ 14 ;$
PENJUALAN! $\$ E \$ 5: \$ E \$ 14 ;$
PERSEDIAAN!H\$4;
PENJUALAN! $\$ C \$ 5: \$ C \$ 14$
PERSEDIAAN! $\$ B 5)$

f. Kolom K :

$$
=\operatorname{SUM}(H 5: J 5)
$$

g. Kolom L :

$$
=D 5-H 5
$$

h. Kolom M :

$=I F($ L5 = 0; "'; IF $(L 5<20 ;$
"Stok Kurang";
$I F(L 5 \geq 100 ;$
Stok Aman;
"Stok Sedang" $))$

i.Kolom $\mathrm{N}-\mathrm{Q}$ : Pengulangan rumus pada kolom $\mathrm{L}$ dan $\mathrm{M}$

j. Kolom R :

$$
=\operatorname{SUM}(L 5: P 5)
$$

5. Sheet5 : Ringkasan

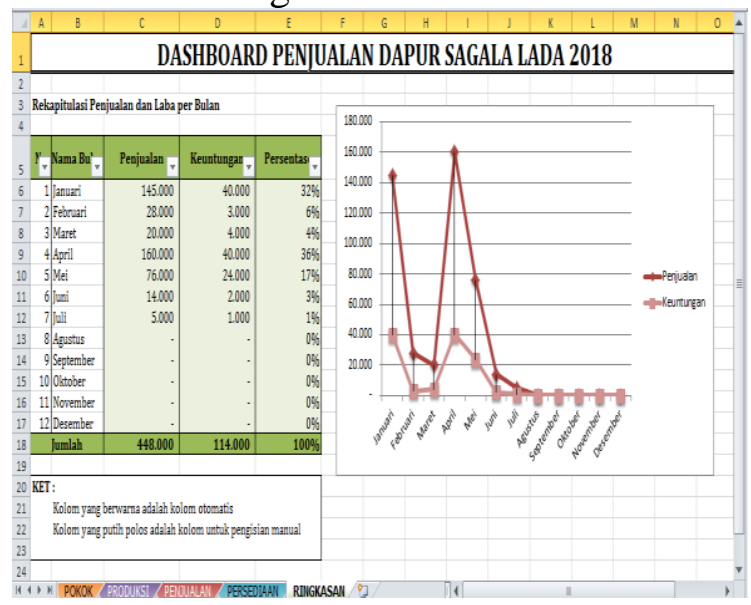

Gambar 3.7 Aplikasi Akuntansi Sheet 5: Ringkasan

Pada lembar terakhir ini pemilik akan dapat melihat secara keseluruhan performa penjualan dan laba yang diperoleh selama satu tahun. Angka pada kolom C dan D pada tabel ini akan terisi otomatis dengan link yang bersumber dari sheet 4. Sedangkan kolom $\mathrm{E}$ diisi dengan mempersentasekan angka pada kolom laba terhadap kolom penjualan.

Di sebelah kanan tabel ditampilkan sebuah grafik yang memvisualisasikan tren 
angka penjulan dan laba sepanjang tahun. Dengan begitu, pemilik akan lebih mudah menyimpulkan kinerja usahanya dari bulan ke bulan, apakah naik, turun atau stabil.

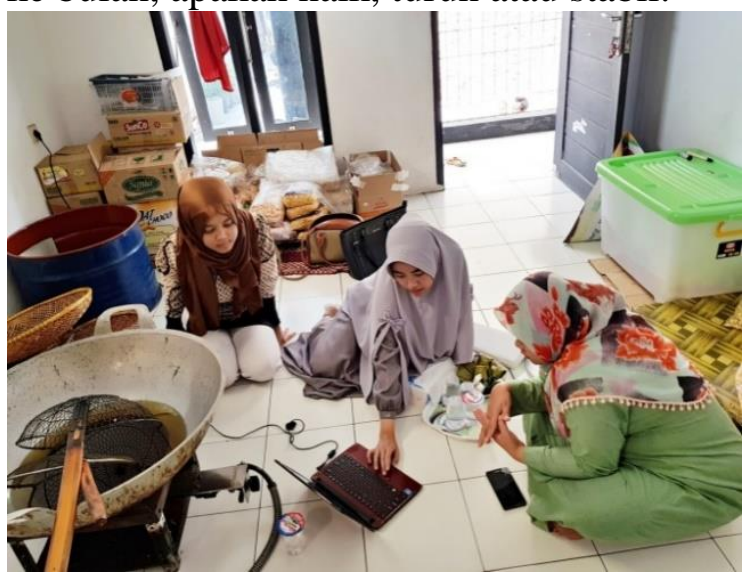

Gambar 3.8

Kegiatan Pengajaran Sistem Informasi Akuntansi dengan Menggunakan Software Microsoft Excel

\section{KESIMPULAN}

Berikut ini adalah beberapa perbaikan terhadap kegiatan bisnis Dapur Sagala Lada

\section{a. Pengadaan Alat Berupa Etalase}

Disini tim kami memberikan sebuah etalase kaca berukuran 1,5 meter.

b. Sistem Informasi Akuntansi

Disini tim kami berupaya memberikan kontribusi pemikiran dengan membuat sistem pembukuan otomatis sederhana menggunakan softwareMicrosoft Excel.

Berdasarkan pengabdian yang telah tim kami lakukan, maka saat ini Dapur Sagala Lada telah memiliki tempat atau fasilitas yang memungkinkan pemilik menyimpan hasil produksinya agar tahan lamadan tidak terkontaminasi suhu dari proses produksi.Hal ini menyebabkan pemilik dapat memproduksi makaroni secara masal dan dapat langsung memenuhi pesanan yang datang.

Selain itu, pembukuan Dapur Sagala Lada saat ini sudah memadai.Pengelolaan keuangan pribadi dan perusahaan sudah terpisah dan sudah diterapkannya konsep kesatuan usaha (entity concept).Selain itu, pencatatan sudah dilakukan secara rutin dan konsisten untuk setiap transaksi pembelian ataupun penjualan yang terjadi:

\section{DAFTAR PUSTAKA}

Badan Pengawas Obat dan Makanan Republik Indonesia. 2012. Pedoman Pemberian Sertifikat Produksi Pangan Industri Rumah Tangga.

Kieso, Donald E, dkk. 2011. Pengantar Akuntansi. Jakarta: Erlangga.

Kotler, Philip and Kevin Lane Keller. 2016. Marketing Management. $15^{\text {th }}$ Edition. New York. Prentice Hall.Pearson International edition.

Singgih, Wibowo. 2007. Pedoman Mengelola Perusahaan Kecil. Jakarta: Niaga Swadaya. 